\title{
E-learning Challenges during the Covid-19 Pandemic Experienced by Students
}

\section{Siti Safura}

Email : sitisafura11@gmail.com

Universitas Muhammadiyah Aceh

ARTICLE INFO ABSTRACT

Article history

Received 27 July 2021

Revised 6 September 2021

Accepted 7 September 2021

Keywords

E-learning

Challenges

Covid-19

Pandemic
The spread of the covid-19 pandemic has changed the teaching and learning process from conventional to e-learning classes. This e-learning class brings out the challenges for students, educators, parents, and institutions. This present study was aimed to see the e-learning challenges faced by students during the Covid-19 pandemic. The participants of this study were 40 students at the Islamic Faculty of Muhammadiyah Aceh University. The qualitative descriptive was applied to analyze 20 questionnaires that were distributed through a google form. The questionnaire was divided into four sessions of challenges that involve internet connectivity, facilities support, technology competence, and selfregulation. This study revealed that students faced problems with the internet, devices, and self-regulation, while technology competence did not show significant challenges.

This is an open access article under the CC-BY-SA license.

\section{Introduction}

Covid-19 is a virus that causes death and spreads very fast to almost all the world. This virus was firstly found in Wuhan, China, in 2019. However, it was detected earlier in 2020, so the World Health Organization (WHO) declared this virus a global pandemic in March 2020 (World Health Organization, 2020). A pandemic is a disease spreading in multiple countries worldwide at the same time (Roxby P, 2020). To prevent the spreading of this virus, every country implements a new policy such as ordering lockdown by working from home, having limited service, and enforcing health protocol and social distancing in the community centre. No doubt, the presence of this virus affects all life sectors, including education.

Education is a process to transfer knowledge from teacher to learners. Normally, education runs face to face between educators and learners. The teacher gives teaching in the class, students listen to the teacher, and students do many activities in the school. However, during the covid 19 pandemics, the educational activities run abnormally by having teaching and learning process at home through online classes. 
Online learning is considered a proper technology to facilitate the teaching learning process during the covid 19 pandemics. This technology eases the educator to deliver information and knowledge to their students. Online learning is software including services to assist teachers in managing their course (Ouadoud et al., 2016). This e-learning requires educators to interact with students to deliver material or have a classroom without a physical classroom. The process of learning and learning content is done online in real-time, and students can participate in courses from anywhere without attending the physical classroom. The use of online learning is practical since it can be used anywhere and anytime.

According to Wentling (2019), online learning is the acquisition and use of knowledge distributed and facilitated primarily by electronic means. It is a tool that gives educators, students, and parents access to general resources (Bagata, 2020). This e-learning indeed assists teachers to implement and improve their online teaching and help students understand more knowledge they get from the online class. Basilaia and Kvavadze (2020) mentioned that e-learning is considered an alternative solution in a pandemic.

Apart from this, e-learning could not be implemented as expected. The form of online learning depends on the network (e.g., wireless, satellite) and the technology (e.g., computer, laptop, smartphone) used (Syauqi et al., 2020). E-learning requires an internet network to access all information. Laptop and computer are also needed to enter the online classroom and interact with teachers and friends. Internet connectivity and ICT equipment become the main key in learning via online. Additionally, the ability to carry out the online platform is needed in order to overcome the trouble during an online class. No experience or lack of information in implementing e-learning could raise the problems (Zaharah, \& Kirilova, 2020).

Further, e-learning is unlike face-to-face learning. When studying in an e-learning environment, especially where it is done as an independent self-study (fully online), one requires a significant amount of discipline and motivation to succeed (Golladay, 2000; Serwatka, 2003). It is due to learners' need to learn by themselves in which they try to understand the given material without listening to teachers directly. Also, learners must encourage themselves to study harder to obtain the given information. On the other hand, when students learn in a conventional class, it is believed that they will learn with an enthusiast where they could interact and participate.

For that reason, the present study aims to find out the challenges faced by students in using elearning during the covid-19 pandemic at the Islamic Faculty of University Muhammadiyah Aceh. More than two semesters, students do not seem to have any problem with their online class. However, some cases found that some students lose their interest in learning. Mahyoob (2020) revealed that the covid-19 pandemic has transformed the education process to online in almost all universities worldwide. Altering the conventional method to the online method in teaching is 
definitely not easy and simple (Atsani, 2020). All education levels pose their own problems in implementing e-learning, such as facilities, network, time, cost, habit, and knowledge.

Numerous studies have been conducted regarding e-learning challenges during the covid-19 pandemic. A study conducted by Alawamleh et al. (2020) specifies that students prefer classroom classes over online classes due to lack of motivation, understanding of the material, and decreased communication levels between their instructors or teachers and their feeling of isolation caused by online classes. It is in line with Yuzulia (2021) who found that students lose their motivation, are more stressed, and bored or distracted during the learning process. Additionally, the students claim that conventional learning is easier than e-learning in which the implementation of e-learning is less optimal. The teacher mostly sends material without explaining, resulting in the students being more anxious because they cannot fully understand the lesson.

Another study conducted by Agung, Surtikanti and OP (2020) claimed that most students were not ready with the rapid change in terms of teaching and learning style including availability and sustainability of internet connection, accessibility of teaching media, and compatibility of tools to access the media. A study conducted by Mahyoob 2020) revealed that students were not satisfied with the implementation of e-learning in terms of internet connectivity and learning access. Learners could not effectively interact with teachers during the class, and online exams could not be opened on learners' mobile phones and courses' materials could not be downloaded. Muthuprasad et al. (2021) specified technology constraints as the inability to handle information and communication technologies effectively. Additionally, students said the connectivity issues in rural areas make it a challenge for them to use online learning initiatives. It is in line with a study (Mohammad Riza Zainuddin, 2020) that shows that learners have difficulty with internet network signals in their respective residence location and the use of internet quota more than before this online learning.

Another problem of students during online learning is the limited supporting facilities, and inactivity in following learning (Efriana, 2021). Students do not have devices such as gadgets and computers as online learning media. Inadequate facilities prevent students from following the class and submitting the assignment as scheduled. A study by Aini et al. (2020) also indicates that elearning support (lacking in suitable devices) and self-regulation (low motivation) become issues in implementing e-learning.

Most of these challenges are related to accessibility (internet network), facilities (laptop, mobile, and computer), technology (readiness of using e-media), and learning boost (less enthusiasm). It is no doubt that these challenges carry out a bad quality in the teaching learning process. It is in line with a review conducted by Nambiar (2020) that perceives online learning lacks quality in implementing the learning process. Flow of classes, lack of interest, technical issues, 
and lack of motivation to attend the classes become the prominent factors reducing the effectiveness of e-learning. All in all, the review on the aspect that hinders the implementation of elearning delineates a reason to identify the challenges of e-learning experienced by students.

\section{METHOD}

The study employs a qualitative research method. Creswell (2014) highlighted that qualitative research is a helpful method to achieve the research objectives smoothly. Moreover, Sutton \& Austin (2015) point out that qualitative research can help researchers access the thoughts and feelings of research participants, enabling the development of an understanding of the meaning that people ascribe to their experiences. Hence, the study is driven to answer the question: "What are the e-learning challenges confronted by students during the covid-19 pandemic?"

The participant of the study was 40 students at Islamic Faculty of Muhammadiyah University Aceh. The study was conducted after the students experienced online learning for more than two semesters. An online survey based on questionnaires was designed to collect the data, allowing the researchers to see the factors of e-learning challenges. The factors include connectivity, facility, technological competency, and self-regulation. The questionnaire contains 13 multiple questions and 2 open-ended questions which cover the study' objectives. Then, the questionnaire was designed by using Google form and distributed online among students using WhatsApp group. This questionnaire was adapted from Aini et al. (2020). Last, the obtained data of the questionnaire was interpreted and described descriptively. Richards \& Schmidt (2002) propose that descriptive analysis is an investigation to describe accurately and factually about a phenomenon that has occurred.

\section{DISCUSSION}

The study divides four sections in order to find out all factors of challenges experienced by students. The obtained result of questionnaires is presented under the following theme below:

\section{Connectivity challenges}

The finding reveals that $92,5 \%$ of students have poor internet connectivity, and only $7,5 \%$ of students do not have a problem with it. Then, followed by limitation in internet data with $85 \%$ of students respond 'yes', while $15 \%$ of students say 'no'. Last, $80 \%$ of students report that they have problems with signal in their area and problem with their money to top up data. Meanwhile, 20\% of students reported no problem with these terms. All indicate that such conditions are common because of its limited network facilities and the limitedness of students to pay more data. The figure below displays the detailed data of connectivity challenges in online classes during the covid-19 pandemic. 
Table.1 CONNECTIVITY CHALLENGES

\begin{tabular}{lll}
\hline \multicolumn{1}{c}{ Statements } & Yes (\%) & No (\%) \\
\hline Poor internet & 92,5 & 7,5 \\
Limitation in internet data & 85 & 15 \\
Low signal in a rural area & 80 & 20 \\
Lack of cost to top up internet data & 80 & 20 \\
\hline
\end{tabular}

\section{Facilities challenges}

This result shows a similar response pertaining to lack of appropriate devices, which is $50 \%$ of students chose 'yes' and 'no'. Regarding available devices, only 32,5\% of students have problems with devices and $67,5 \%$ have no problem with the device. Further, regarding lab computers, $80 \%$ of students respond 'yes' and 20\% respond 'no' as most students have their own devices. They do not need to come to the lab to use the media or tool in accessing material or following class. The detailed data of facilities challenges through e-learning during the covid-19 pandemic are as below.

Table.2 FACILITIES CHALLENGES

\begin{tabular}{lll}
\hline \multicolumn{1}{c}{ Statements } & \multicolumn{1}{c}{ Yes (\%) } & No (\%) \\
\hline Lacking in suitable devices/tool & 50 & 50 \\
No available devices/tool & 32,5 & 67,5 \\
No computer lab session & 80 & 20 \\
\hline
\end{tabular}

\section{Technology competency challenges}

Based on the finding, only 7,5\% of students report having problems with ICT knowledge, and $92,5 \%$ of students do not have a problem with technology competency. Regarding readiness in using ICT, $52,5 \%$ of students report not being ready to use ICT, while $47,5 \%$ of students are ready to use ICT in learning. Then, $30 \%$ of students inform that not able to use learning media and access learning material, while $70 \%$ of students can use learning media and access learning material. Last, in following the class and submitting the assignment, $25 \%$ of students report no problem, but $75 \%$ have a problem with this term. The condition indicates that students understand the technology and on hand in learning through e-learning. The percentage of detailed data about technology competency challenges in e-learning during the covid-19 pandemic is Table 3. 
Table.3 TECHNOLOGY COMPETENCY CHALLENGES

\begin{tabular}{|c|c|c|}
\hline Statements & Yes (\%) & No (\%) \\
\hline $\begin{array}{l}\text { Lack of Knowledge ICT } \\
\text { communication technology) }\end{array}$ & 7,5 & 92,5 \\
\hline Readiness of using ICT & 52,5 & 47,5 \\
\hline Unable to use learning media & 30 & 70 \\
\hline Unable to access learning material & 30 & 70 \\
\hline $\begin{array}{l}\text { Unable to follow the class or submit the } \\
\text { assignment }\end{array}$ & 25 & 75 \\
\hline
\end{tabular}

\section{Self-regulation challenges}

The finding on the e-learning challenges shows that $92,5 \%$ of students do not have motivation in learning, only $7,5 \%$ of students do not have a problem with their motivation to learn. $72,5 \%$ of students got difficulty in learning and could not concentrate or focus on their learning class, and only $27,5 \%$ of students could focus and follow the class even during the e-class. The reluctance to learn and less awareness to learn felt by only $32 \%$ of the students while $68 \%$ keep learning through e-learning. Regarding learning interest, only $20 \%$ of students are less interested when they used e-learning and $80 \%$ of students reported no effect with this term. In maintaining communication with friends, the students have difficulty talking or sharing about their learning, which is $52 \%$, while $48 \%$ of students found no difficulty in communicating with friends. The last, $92,5 \%$ of students actively responded that they have difficulty in communicating with their lecturer and only $7,5 \%$ of students said that it was easy to communicate with their lecturer. It is due to the indirect meeting with their lecturer in which they cannot talk face to face. The detailed data of these challenges are displayed as below.

Table.4 TABLE 4.SELF-REgULATION CHALLENGES

\begin{tabular}{|c|c|c|}
\hline Statements & Yes (\%) & No (\%) \\
\hline Low motivation & 92,5 & 7,5 \\
\hline Learning difficulties & 72,5 & 27,5 \\
\hline Less concentrate & 72,5 & 27,5 \\
\hline Reluctance of learning & 32 & 68 \\
\hline Lack of learning interest & 20 & 80 \\
\hline Lack of learning awareness & 32 & 68 \\
\hline $\begin{array}{l}\text { Difficult to maintain communication with } \\
\text { peers/friends }\end{array}$ & 52 & 48 \\
\hline $\begin{array}{l}\text { Difficult to maintain communication with } \\
\text { teachers/lecturers }\end{array}$ & 92,5 & 7,5 \\
\hline
\end{tabular}

Based on the result the overall result of e-learning challenges faced by students during the covid-19 pandemic is displayed in the form of the figure below: 


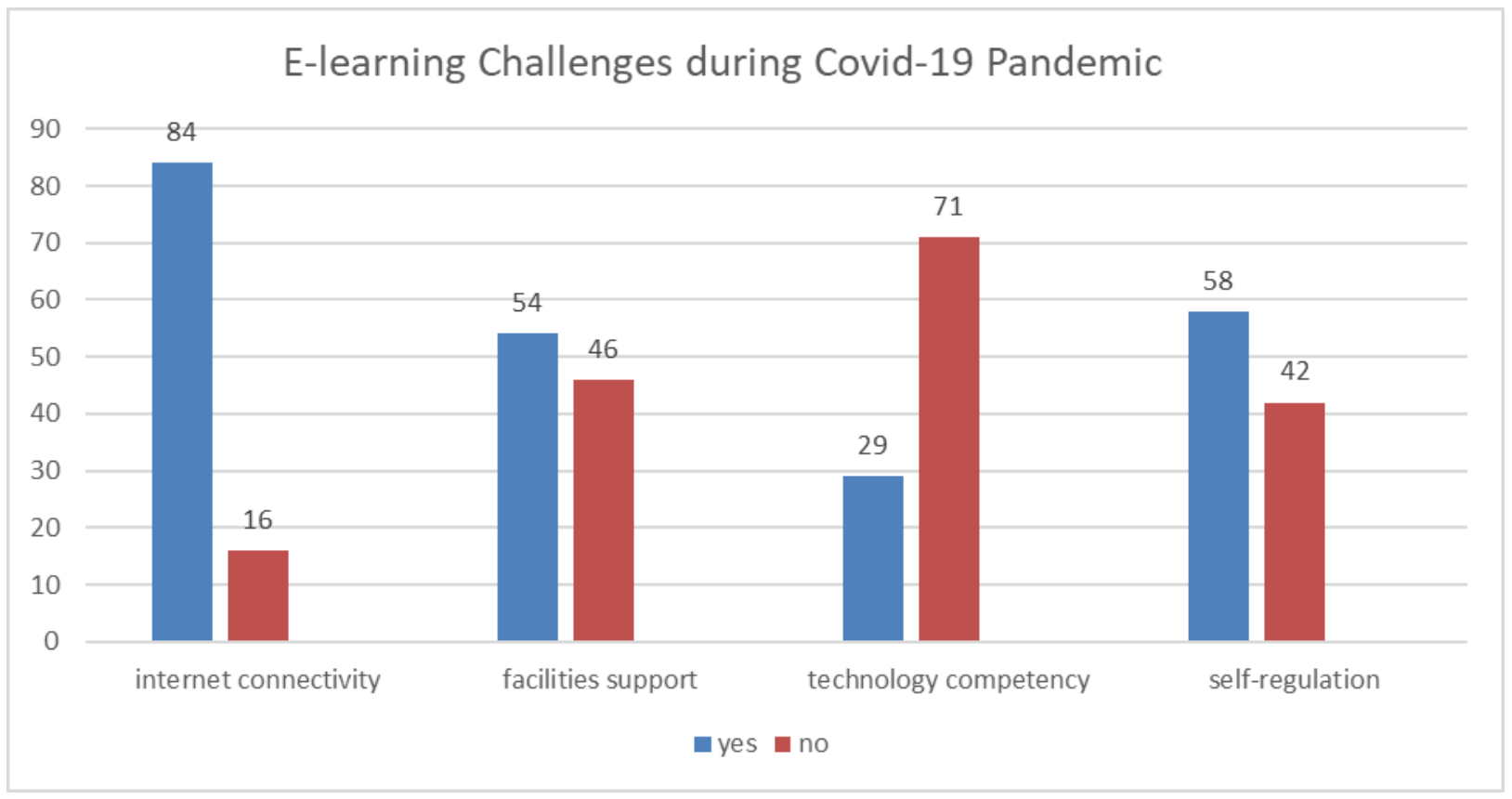

Figure 1. The overall result of e-learning challenges during the covid-19 pandemic

Conducting learning indirectly through e-learning indeed comes with many challenges. The present study aimed to investigate the challenges of e-learning faced by students during the covid19 pandemic. The study reveals that internet connectivity is the dominant aspect that is an issue in learning online in which $84 \%$ of students experienced some obstacles to join the online class. It ly different with $16 \%$ of students who do not have problem with the internet. The significant difference indicated that the internet network is highly influential in learning by using e-learning. The source of the internet is the materials needed to reach the teaching and learning process goals online (Surtikanti, 2020). The students who want to join the class need the internet to access the material, receive the information from the lecturer, deliver the assignment, and so on (Efriana, 2021). Poor connection creates the online class disruption and loses interaction and communication during online class (Agung et al., 2020; Al-Balas et al., 2020; Yuzulia, 2021). Students in remote areas will commonly face difficulty downloading the material, accessing online learning, and online exams (Mahyoob, 2020). Not only that, the issue about the cost in which the students need to have a sufficient quota of internet data to access the classroom is committed as an obstacle through e-learning (Agung et al., 2020; Efriana, 2021).

Further, as noticed from the figure above, the challenges of e-learning are related to facilities support and self-regulation reveal the almost average result. The facilities' difficulty and selfregulation depict about 50\% of students respond 'yes' and 'no' with an average of $40 \%$. Such conditions indicated that students also have obstacles with each aspect. Beside the internet 
network, facilities such as laptops, computers, and mobile to connect with online classes are entirely needed. At the same time, teachers and students carry out the class together in a different place. However, not all students have an adequate tool to join class via online (Efriana, 2021). As a result, students could not follow the class and missed information from the teachers.

In self-regulation challenges, students face difficulty in terms of their mood in learning. The students' feelings in learning will influence their enthusiasm to follow the class. Students will be less concerned about their condition to join the class and tend to be ignorant about their assignment submission (Efriana, 2021). Lack of interest and motivation in learning brings out a disturbance in the flow of the class (Nambiar, 2020). Not only that, self-regulation will affect how the students interact and communicate with their friends and lecturer. The ineffective communication and interaction prevent students from receiving and understanding all information in the learning process (Alawamleh et.al, 2020; Aini et al., 2020).

Regarding technology competence, the result revealed the opposite responses in which the more students selected 'no' than 'yes'. It indicated that the majority of students do not have problems with their competence to use technology (Aini et al., 2020). In this era, most students do not have problems with technology. Students could afford every issue related with technology since technology has become an important part of this era. The competence of students in mastering technology is doubtless well versed. The use of technology makes students more excited to follow and respond to the classroom efficiently (Sun \& Chen, 2016).

\section{CONCLUSION}

All level of education experiences its own problems in implementing e-learning during the covid-19 pandemic. The implementation of an e-learning system relies on addressing the way to overcome the challenges faced by the students. However, using e-learning has the problem that influences student's performance and learning outcomes. The present study revealed four challenges confronted by students in using e-learning during covid -19. It was found that the major challenges experienced by students in using e-learning are regarding the internet connection. The second challenge was students' self-regulation, indicating that they had less motivation and could not maintain communication with lecturers. The third, the facilities support showed the almost similar finding between 'yes' and 'no' felt by students through e-learning. Last, the fourth challenges considered as difficulty during e-learning faced by students show the significant difference result in which the students do not seem to have a problem with technology competence. It perhaps due to the majority of students surely understand how to utilize the technology. So, it is recommended for the next study should be undertaken to see the lecturers' views and experiences toward elearning during the Covid-19 pandemic. 


\section{REFERENCES}

Agung, A. S. N., Surtikanti, M. W., \& OP, C.A.Q. (2020). Students' Perception of Online Learning during COVID-19 Pandemic: A Case Study on the English Students of STKIP Pamane Talino. SOSHUM: Jurnal Sosial Dan Humaniora, 10(2), 225-235. https://doi.org/10.31940/soshum.v10i2.1316

Aini, Q., Budiarto, M., Putra, P. O. H., \& Rahardja, U. (2020). Exploring E-learning Challenges During the Global COVID-19 Pandemic: A Review. Jurnal Sistem Informasi, 16(2), 57-65. https://doi.org/10.21609/jsi.v16i2.1011

Al-Balas, M., Al-Balas, H. I., Jaber, H. M., Obeidat, K., Al-Balas, H., Aborajooh, E. A., Al-Taher, R., \& AlBalas, B. (2020). Correction to: Distance learning in clinical medical education amid COVID19 pandemic in Jordan: current situation, challenges, and perspectives (BMC Medical Education, (2020), 20, 1, (341), 10.1186/s12909-020-02257-4). BMC Medical Education, 20(1), 1-7. https://doi.org/10.1186/s12909-020-02428-3

Atsani, K. L. M. Z. (2020). Transformasi Media Pembelajaran Pada Masa Pandemi Covid-19. Al$\begin{array}{lllll}\text { Hikmah: } & \text { Jurnal } & \text { Studi } & \text { 82-93. }\end{array}$ http://ejournal.kopertais4.or.id/sasambo/index.php/alhikmah/article/view/3905

Bagata, D. T. R. (2020). EFL University Students' Perception of the Use of Online Learning Platform in the Covid 19 Pandemic. Jurnal Penelitian, Pendidikan, Dan Pembelajaran UNISMA, 15(34). http://riset.unisma.ac.id/index.php/jp3/article/view/8102

Basilaia, G., \& Kvavadze, D. (2020). Transition to Online Education in Schools during a SARS-CoV-2 Coronavirus (COVID-19) Pandemic in Georgia. Pedagogical Research, 5(4). https://doi.org/10.29333/pr/7937

Creswell, J. W. (2014). Research Design : Qualitative, Quantitative, and Mixed Methods Approaches. SAGE Publication,

Inc. https://www.researchgate.net/publication/31763471_Research_Design_Qualitative_Quanti tative_and_Mixed_Methods_Approaches_JW_Creswell

Efriana, L. (2021). Problems of Online Learning during Covid-19 Pandemic in EFL Classroom and the Solution. 2(1), 38-47.

Golladay, R.M, R.A. Huff, V. R. P. (2000). Critical success factors for the online learner. Journal of Computer Information Systems, 40(4), 69-71.

Mahyoob, M. (2020). Challenges of e-Learning during the COVID-19 Pandemic Experienced by EFL Learners. 11(December), 351-362.

Alawamleh, M., Al-twait, L. M., \& Al-Saht, G.R. (2020). The Effect of Online Learning on Communication Instructors and Students During Covid-19. Asian Education and Development Studies, 9(4), 1-12. 
Mohammad Riza Zainuddin. (2020). ONLINE LEARNING CHALLENGES IN CENTRAL PANDEMIC VIRUS CORONA IN STAI MUHAMMADIYAH TULUNGAGUNG Mohammad. Edukasi: Jurnal Pendidikan Islam, 8(1), 129-138. https://ejournal.staimtulungagung.ac.id/index.php/edukasi/article/view/457

Muthuprasad, T., Aiswarya, S., Aditya, K. S., \& Jha, G. K. (2021). Students' perception and preference for online education in India during COVID -19 pandemic. Social Sciences \& Humanities Open, 3(1), 100101. https://doi.org/10.1016/j.ssaho.2020.100101

Nambiar, D. (2020). The impact of online learning during COVID-19: students' and teachers' perspective. The International Journal of Indian Psychology, 8(2), 1-12.

Ouadoud, M., Chkouri, M. Y., Nejjari, A., \& El Kadiri, K. E. (2016). Studying and comparing the free elearning platforms. Colloquium in Information Science and Technology, CIST, 0(October), 581-586. https://doi.org/10.1109/CIST.2016.7804953

Richards, J.C. and Richards, S. (2002). Dictionary of language teachng and applied linguistics. Longman.

Roxby P. (2020). Coronavirus Confirmed as Pandemic by World Health Organization. BBC News. https://www.bbc.com/news/world-51839944.

Serwatka, J. A. (2003). Assessment in Online CIS Courses.No Title. Journal of Computer Information System, 43(3), 16-20.

Sun, A., \& Chen, X. (2016). Online education: perspectives on a new environment. Journal of Information Technology Education, 15, 157-190. https://doi.org/10.5860/choice.28-0430

Surtikanti, M. W. (2020). Textbook Evaluation on Curriculum 2013-Based Textbook "When English Rings A Bell" for the Seventh Grade. JOEEL: Journal of English Education and Literature, 1(1), 11-17. https://doi.org/10.38114/joeel.v1i1.22

Sutton, J., \& Austin, Z. (2015). Qualitative research: data collection, analysis, and management. The Canadian Journal of Hospital Pharmacy, 68(3), 226-231.

Syauqi, K., Munadi, S., \& Triyono, M. B. (2020). Students' perceptions toward vocational education on online learning during the COVID-19 pandemic. International Journal of Evaluation and Research in Education, 9(4), 881-886. https://doi.org/10.11591/ijere.v9i4.20766

Wentling, T. L. (2019). E-learning: A review of literature e-learning - A Review of Literature Prepared by (Issue March, pp. 1-60). NCSA: The University of Illinois. https://www.researchgate.net/publication/331938876_E-learning_A_review_of_literature

World Health Organization. (2020). Covid-19 Situation Report. World Health Organization, 31(2), 61-66.

Yuzulia, I. (2021). The Challenges of Online Learning during Pandemic: Students' Voice. Wanastra: Jurnal Bahasa Dan Sastra, 13(1), 08-12. https://doi.org/10.31294/w.v13i1.9759 
Zaharah, Galia Ildusovna Kirilova, and A. W. (2020). Impact of Corona Virus Outbreak Towards Teaching and Learning Activities in Indonesia. SALAM: Journal Social and Budaya Syar'i, 7(3), 269-282. http://www.journal.uinjkt.ac.id/index.php/salam/article/view/15104 